\title{
The Management of Waqf Universities in Selangor, Malaysia
}

\author{
Mohd. Ali Muhamad Don ${ }^{1}$, Muhamad Rahimi Osman ${ }^{2}$ \\ ${ }^{1}$ Academy of Contemporary Islamic Studies, University Teknologi MARA, \\ Pasir Gudang Campus, Johor, Malaysia. \\ ${ }^{2}$ Academy of Contemporary Islamic Studies, University Teknologi MARA, \\ 40450 Shah Alam, Selangor, Malaysia. \\ ${ }^{*}$ Corresponding Author \\ 73khawarizmi@uitm.edu.my
}

Received: 4 June 2020

Accepted: 3 July 2020

Online First:

\begin{abstract}
In Malaysia, waqf management including those in universities, is under the authority of the State Islamic Religious Council as a sole trustee waqf. This is to protect the waqf assets from any interventions by the heirs. Even so, one Malaysian university is said to manage the waqf scheme without the supervision of the Islamic Council which contradict with the provision of the State of Islamic Religious Council (SIRC) as the sole trustee of waqf. Thus, this study explores the management of waqf by several universities in Selangor and relation to SIRC as the sole trustee of waqf. A qualitative research approach was employed to collect data from focus group discussions and interviews with selected participants from the Selangor Islamic Religious Council (Selangor IRC), selected universities and waqf experts in Malaysia. The findings show that University Kebangsaan Malaysia and University Putra Malaysia waqf funds are managed under the Selangor IRC monitoring while University Islam Antarabangsa Malaysia endowment or waqf fund is managed privately by the university. The impact of this is that several waqf management issues arose. Hence, the authors recommend the Model theory of al-wilayah to be applied in the management of waqf in the universities. Through this model, SIRC and the university can

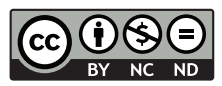


Journal of Contemporary Islamic Studies

play a more significant role in the management of waqf, thereby promoting the development of waqf in Malaysia.

Keywords: Waqf Management, Waqf University Scheme, Waqf Management Issues

\section{INTRODUCTION}

Waqf is important as a wealth distribution mechanism in the country (Nurul Hilmiyah, 2013) including providing educational opportunities to improve the standard of living (Sayyed, 1989). The relationship between waqf and education is very significant to the role of initiating, strengthening and developing educational institutions (Hassan Langgulung, 1987; Rosnani \& Abdul Karim, 2000). In fact, waqf serves to provide free education to society beyond the borders of race, religion and country (Makdisi, 1981).

The management of waqf by the government, it is said to begin in Egypt and Syria when waqf property is increased and fears of irregularities occur. The individual who first set up a special department on the management of waqf was Tawbah bin Namir (Abu Zahrah, 2009). There after established specialized departments for legal and supervisory purposes. According to Monzer Kahf (2003), in the $8^{\text {th }}$ century Egyptian Kadi established the Special Registrar's Office to register and regulate all the wakaf. In the $13^{\text {th }}$ century Hijrah the Ottoman government set up the Waqf Ministry and introduced a legal provision that placed all the treasury properties under the control of the rulers.

In Malaysia, the State Islamic Religious Council (SIRC) by the British was first established in Selangor in 1952. At the same time, it was also enacted by the State Islamic religious law which included the provision of waqf and the determination of SIRC as a waqf sole trustee (Saad et.al., 2017). However, this ruling does not coincide with the Islamic law which empowers waqf management to trustees appointed based on the theory of al-wilayah khassah and special waqf (Tunku Alina Alias \& Murat Cizakca 2014). 
Hence the paper aims to describe the waqf management by the universities in relation to the waqf management by SIRC as well as to examine the issues arising based on the introduction and management of waqf scheme by the several universities.

\section{METHODOLOGY}

This study is a descriptive qualitative approach study using focused data interviews and literature reviews as a primary data source. Study samples were selected from officials involved in the waqf management at Selangor Islamic Religious Council, waqf scheme administrators at selected universities in state of Selangor and expert in waqf field in Malaysia. Universities implementing the waqf scheme as one of the methods of funding education in Selangor such as University Kebangsaan Malaysia (UKM), University Putra Malaysia and University Islam Antarabangsa Malaysia are selected. The data obtained were transcribed and analyzed using the Atlas.ti application and reported partly in this paper. Triangulation data methods between interview data, literature review and field observations were performed to confirm the findings of the study.

\section{RESULT}

Prior to the enactment of the Administration of Islamic Law Enactment Selangor 1999 (AILES 1999), waqf property was administered by waqif, community leaders and mosque committees (Kamarudin Ngah, 1992), as no written law was adopted by State of Islamic Religious Council (SIRC) (Rohayati \& Rusnadewi, 2015). The implementation is simple and is not abuse by the Nazir nor the invasion of the property of waqf. The implication is that there are many waqf land for pondok schools, madrasahs, mosques and cemeteries that lasted until today (Baharuddin, 2006).

After independence of Malaysia the implementation and management of waqf is subject to the Federal Constitution and enactment at state level (Sharifah Zubaidah \& Nuarrual, http: //www.iefpedia.com). Among them is Article 74 (2) of the Federal Constitution which empowers the State Legislature to enact laws relating to religious matters including waqf (Sayuti, 
2011). The drafting of the law was done with the Administration of Islamic Law Enactment (Rohana, https: //www.academia.edu).

Furthermore, SIRC is a sole trustee waqf (Siti Mashitoh, 2007). Therefore, no party other than SIRC has the power to be a sole trustee. All treasury assets belong to SIRC and all agreements relating to waqf are kept by SIRC (Rohana, op.cit.). Similarly, all applications for waqf need to be registered in the name of SIRC including all property transfer procedures where the waqf assets are created (Siti Mashitoh, 2010). In the event of a dispute related to the instrument or concourse of SIRC, they refer to the Mufti or the State Fatwa Committee to resolve it (Mohd Afandi \& Siti Fatahiyah, 2015).

The findings show that there are at least four management methods of waqf by universities in Selangor namely; MoU-based management such as the MoU between Selangor IRC with UKM and UPM, independent management by UIAM, direct management by Selangor IRC towards the property of Kolej University Islam Selangor and fully waqf management with the consent of the Malay Rulers Council as in the University Islam Malaysia. However in this paper only two waqf management methods discussed which is collaboration with Selangor IRC and self-managed by the university. The universities that are fully funded by waqf funds like University Islam Malaysia in Cyberjaya are not included in this study.

In the case of self-management, UIAM introduced a waqf scheme based on the endowment fund concept (Maliah et.al, 2009) under the management of the IIUM Endowment Fund (IEF). IEF is responsible for funding, managing, granting scholarships and investing money to generate profits (http://www.iium.edu.my/ief/vision) without collaboration with Selangor IRC. This is because, UIAM applies the term endowment fund which is generally not subject to the enactment of waqf and was introduced earlier prior to the drafting of AILES 1999.

UKM introduced a waqf based university concept (Siti Mashitoh \& Asmak, 2014) under the management of UKM Chancellor's Office and is responsible for donating, generating finance and working with other responsibilities centers to generate and manage donations (www. ukm.my/yc). UPM also introduced the concept of Wakaf Ilmu to fund 
university academic activities and provide scholarships to students under the supervision of the Waqf, Zakat and Endowment Management Center (WAZAN) to bring UPM philanthropic management more efficiently and effectively.

Among other things, the University's MoU with Selangor IRC contains the consent that all procurements of the UKM Wakaf Ilmu Fund should be submitted to Selangor IRC and kept in the UKM Waqaf Fund account. UKM parties should apply to Selangor IRC to utilize the benefits with the consent of joint committees between Selangor IRC and YC UKM representatives.

As regards to the relationship with UPM, Selangor IRC has signed the MoU with the UPM Vice-Chancellor. The accumulated funds are deposited by Selangor IRC in the Special Account of Dana Wakaf Ilmu UPM. The Syariah Committee of the UPM Wakaf Fund and the UPM Wakaf Ilmu Committee are the committees comprising representatives from Selangor IRC and UPM (http://www.upm.edu.my). Through this agreement, Selangor IRC as a sole trustee has granted UPM permission to collect and receive money, assets and property for the purposes of waqf and invest and distribute the profits earned.

\section{DISCUSSION}

According to the finding above there are some issues from management side and legislative issues. This is based on the findings of the interviews data with selected participants mentioned below;

\section{Issues of Waqf Management by Islamic Council}

Sec. 89 AILES allocates Selangor IRC as a sole trustee. But the university collects funds and must hand over all the waqf assets to Selangor IRC. According to these issues some participants says SIRC as a whole is not open-minded and fails to manage waqf well (P07: 2015). In fact, SIRC faces expertise issues in developing waqf $(\mathrm{P} 06,2015)$, like lack trained staff (P07: 2015), existing waqf assets cannot be developed and also issues of bureaucratic registration of waqf (P02, 2015); Rohayu \& Rosli, 2014). Additionally, with the intervention of the Council in the management of the 
university's waqf fund, it should only be regulated by SIRC. Regardless, waqf management as mentioned previously, can be harmonized with all parties playing their respective roles. SIRC for example can act as an advisor and law enforcement rather than interfere with all those things that are unlikely to be managed. In fact, SIRC does not have the absolute power in managing waqf instead to act as planning coordinator and monitoring.

\section{Issues of Waqf Management by Universities}

Interviews findings show that there are administrative, mentality and marketing issues within the management of university's waqf fund (P07, 2014). In addition, there is a waqf management issue led by the academic staff who only serves on a contract for a certain period (P06, 2014). Administrative staff also has the potential to be transferred to another department $(\mathrm{P} 06,2014)$. It is more aggravating that university management does not understand the concept of waqf and equates it to the concept of endowment which is practiced in the West (P02, 2015). Also, the public's lack of understanding of the waqf concept in the university led to problems in obtaining funds $(\mathrm{P} 08,2015)$. The difficulty of getting people to know where and how their waqf contributions are spent also causes them to refuse to pay $(\mathrm{P} 04,2014)$. There is also a problem of promotion and marketing of university waqf schemes $(\mathrm{P} 02,2015)$ due to the failure to mobilize alumni potential (P06,2014).

In this regard, universities that introduce waqf schemes can look at this issue positively to strengthen the management of waqf. Failure to do so reveals the management of the university waqf to criticisms and defamation which illustrates the image of universities and practice in general. This is also a factor why staff of the universities are not willing to contribute to waqf scheme while the potential of this fund is large (P03,2015).

\section{Legal Issues of University's Waqf Fund Scheme}

There are waqf legal issues arising from the introduction of waqf scheme in the university. This is because the AILES 1999 provisions make the management of general waqf and special waqf located under the exclusive jurisdiction of Selangor IRC (Che Zuina, 2015). Even with the enactment of such enactment any party who has ever been appointed as 
waqf trustee shall deliver all waqf property to Selangor IRC without any conditions (Baharuddin, 2006). Even a denial of the Special Nazir powers to manage waqf is against the role of Nazir responsible for expanding waqf and generating profits. However, through the amendment of AILES 2015 the opportunity to create a special waqf is found to be unfolding. In addition, among the issues arising was the vesting of waqf assets at Selangor IRC while the university raising the funds (P04, 2015). As a result, the university refuses to cooperate with Selangor IRC and refuses to hand over the accumulated waqf funds. So there is a university that uses terms other than waqf to avoid being bound by the enactment. The issue is that the SIRC has yet to determine the university's waqf assets under the jurisdiction and control of any party despite the jurisdiction of SIRC (P04, 2015).

\section{PROPOSED OF MODEL THEORY OF AL-WILAYAH FOR MANAGING UNIVERSITY WAQF FUND}

Selangor IRC provision is the sole trustee that binds management of waqf by any party in accordance with its position as the owner of al-Wilāyah Am (Wakaf Land Acquisition Management Manual, 2010). SIRC as a whole is also an ulil amri who has the power to enact laws to launch the administration of Islam including waqf affairs. Therefore, the power source for university waqf management must be based on the enactment enacted.

At the same time, the role of a waqif or who is appointed as a special landowner in the management of waqf is also important. This is confirmed by the opinion of Ahmad Zaki (2008) which recognizes the role of waqif to manage waqf or appoint other parties to giving waqf to the university. Even al-Imam Abu Hanifah (al-Kabisi, 1977), al-Mawardi, (Al-Baghdadi, 1994), Ibn Abidin (Abdul Mawjud \& Mu'awwad 1994), al-Syarbini (Mu'awwad \& Abdul Mawjud, 1994) stressed al-wilāyah rights over waqif, appointed parties, wasiy and the government in priority.

According to the Islamic Jurisprudence scholars such as al-Mawardi (al-Baghdadi, 1994), al-Wilayah theory is divided into wilayah ammah and wilayah khassah. Where in the context of waqf management, waqif is appointed as wilayah khassah holder and also the owner of the assets and free to manage the waqf according to its intention. This is also in line with 
the Islamic legal maxim which mentions the requirements of the waqif such as syarak will. Whereas Judges or governments have only the wilayah ammah right to ensure that the intention of the arbitrator is fulfilled. This is also agreed by Mohammad Tahir (2015), who confirms that waqf managers in accordance with the priorities are appointed to trustees, courts, local religious authorities and other entities in order.

Therefore, it's recommended that the model theory of al-wilayah be applied in the management of waqf by university in the State of Selangor and in Malaysia generally. Through this recommendation the power of SIRC as a sole trustee waqf is maintained without any amendment.

However, based on the theory of al-wilayyah, the role of SIRC as a sole trustee is devoted to the aspects of monitoring, legislators and enforcement of waqf activities in parallel with the concept of wilayah ammah power set by the syarak. With that Selangor IRC can set any rules for compliance with all parties wishing to be waqif. With this provision, Selangor IRC may require that annual financial reports should be provided by the university to be reviewed, audited and verified. Diagram 1.0, below are the Model Theory of al-Wilayah that can be implemented on the waqf fund management by the university without contradiction with the waqf enactment by the state. 


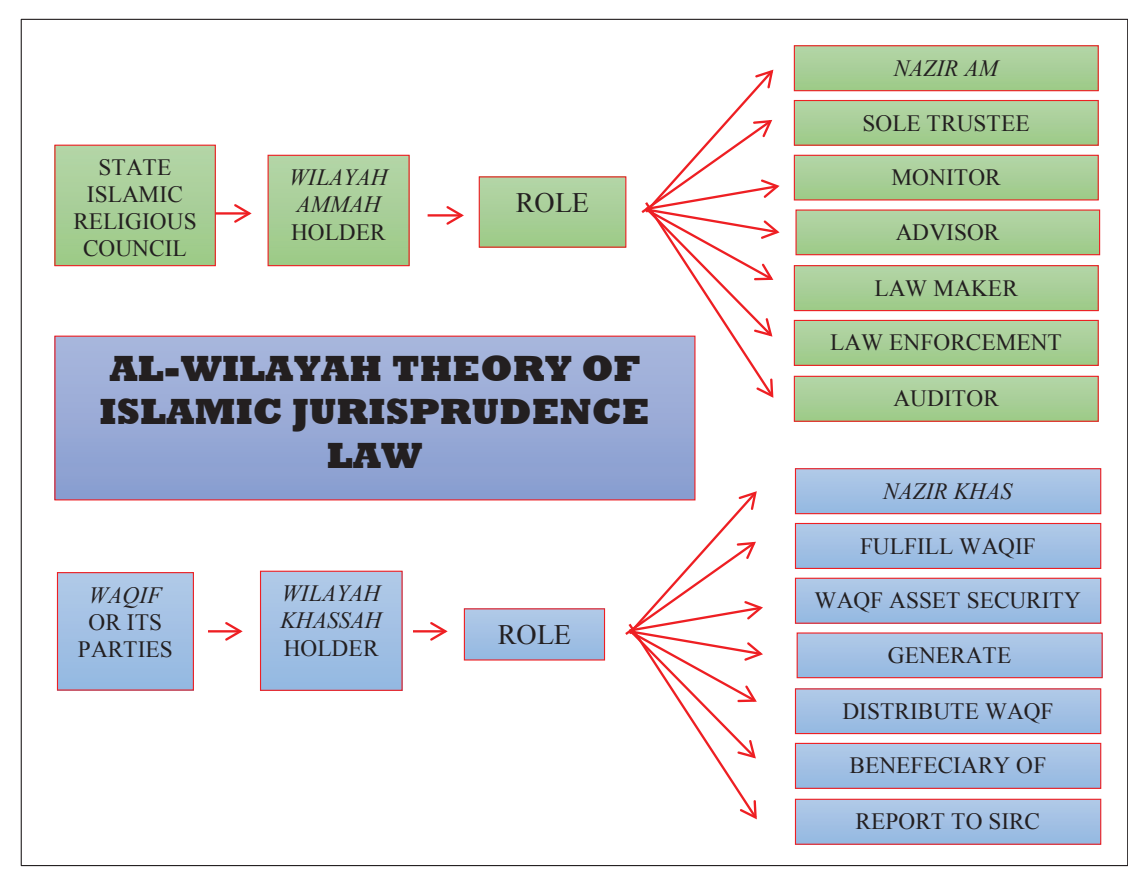

Diagram 1.0: Model Theory al-Wilayah for the waqf management (Mohd. Ali, 2018)

In addition, the authors suggests Selangor IRC recognizes the role of the university as a Special Nazir or mawquf 'alayh to manage the waqf funds. This is done in Brunei that divides the management of waqf registered under the management of the Islamic Religious Council and the management of waqf not registered under the management of waqif or mawquf 'alayh (Mas Nooraini, 2015). Through this method, unregistered waqf management such as equipment donations and others is done verbally with the consent/ arbitration between wäqif and 'mawquf alayh (Harun, 2012). Hence, the management of waqf by private parties is recognized and complies with the provisions of the Council as a sole trustee for all general and special waqf in Brunei (Mariah, 2015).

In Singapore, the Islamic Religious Council of Singapore also appoints private Mutawalli to manage special waqf (Abdul Halim \& Kamarulzaman, 2006), although Islamic Council is a general and special waqf manager in 
Singapore under Section 58 (2) of the Administration of Muslim Law Act (AMLA) 1968. Muhammadiyah Islamic College Singapore (MICS) in Singapore is also authorized to collect funds and develop various higher education projects (Muna, 2013. https://ejurnalfp.files.wordpress.com) while Islamic Council is only involved in development and curriculum purification and teacher quality control. In Indonesia, the management of waqf by Nazir either individually, organization or legal entity is also recognized on the national side of the legislation through the provision of Fifth Division Article 9, Law of the Republic of Indonesia Number 41 of 2004. The introduction of trust schemes that resemble waqf in the West is also managed by private parties without direct intervention by the government unless acting as a regulatory agency, collecting records and information other than providing support and assistance required by the involved institutions (al-Hosain, 2012).

Thus, the university or department that manages waqf is authorized as the Manager of Special Waqf subject to Islamic law and enactment (Siti Mashitoh \& Asmak, 2015). Even any violation of law in the management of waqf funds can eliminate the power of the university as a Special Nazir. SIRC as the Nazir Am (General Nazir) has the power to fire and take over management or appoint other qualified persons to fill the vacancy. This is in line with the university's situation as a party that carries out waqf funds in terms of property acquisition, fund management, benefit distribution and waqf revenue generation. In fact, with all the experience, expertise and facilities available at the university, this management aspect of waqf funds becomes easier and more organized.

\section{CONCLUSION}

It is desirable to maintain and strengthen the SIRC's position as a sole trustee in the management of waqf by universities. This is to create a check and balance process in the management of waqf. This is also to prevent certain parties from taking advantage of the generosity of the Muslim community for personal gain while waqf is the property of Allah for the benefit of the public. 
In order to strengthen the management of waqf by SIRC and the university, both parties are advised to sit down to find the best solution to every issue and problem arise. Both parties are proposed to apply the alWilayah theory model in management of waqf. In this way each participant can play its own role in order to further enhance the development of waqf in Malaysia.

The legal issue regarding SIRC as a sole trustee in management of waqf in the university also should not restrain the implementation of waqf. This is to ensure the survival of waqf while avoiding irregularities and aggression on the property of waqf. Parties wishing to be devoted are also expected not to abandon the provision of the law that recognizes SIRC as a sole trustee. The legal issue of waqf can be resolved harmoniously and creating win-win situation for mutual benefit.

According to the State Mufti of Selangor, the university should be registered in the name of SIRC to manage the waqf and then determine the terms and rights of the university to utilize the waqf. The goal is to keep the property as a waqf property forever, as it cannot be sold nor changed in status without SIRC knowledge.

\section{ACKNOWLEDGMENT}

Appreciation goes to the Ministry of Education which has sponsored this study through The Fundamental Research Grant Scheme (FRGS) Grant Phase 1/2018. Grant Code; FRGS / 1/2018 / SSO 6 / UITM / $02 / 7$. Also to the top management of the MARA University of Johore who has given strong approval and strong support for the writers to conduct field studies to collect data in Majlis Agama Islam Selangor and selected universities in Selangor. 
Journal of Contemporary Islamic Studies

\section{REFERENCE}

Abdul Halim Ramli \& Kamarulzaman Sulaiman, 2006. Pembangunan Harta Wakaf Pengalaman Negara-negara Islam, di bentangkan di Konvensyen Wakaf Kebangsaan, 12-14 September 2006, Hotel Legend, Kuala Lumpur.

Abu Zahrah, Muhammad, 2009. Mukhadārah fi al-Waqf. Kaherah: Dār al-Fikr al-Arabiy.

Ahmad Zaki, MD Norzaidi, I Che Zuina. 2008. Pengurusan Harta Wakaf dan Potensinya Ke arah Kemajuan Pendidikan Umat Islam di Malaysia. Jurnal Pengurusan JAWHAR, Vol. 2, No. 2, Putrajaya: Jabatan Wakaf, Zakat dan Haji, JAWHAR.

Ahmad Zaki, 2008. Wakaf Pengurusan dan Sumbangannya Terhadap Pendidikan Islam di Malaysia. Shah Alam: Pusat Penerbitan Universiti (UPENA) UiTM.

Al-Hosain, Saleh bin Abdul Rahman, 2012. Tatbìqāt al-Waqf Baina al- 'Ams wa al-Yaum. dibentangkan di Mutamar al-Awwal li Jam iyyah Tahfìz al-Qurān, Taif, Saudi Arabia, 2012. diakses pada 6 April 2019. http:// ar.islamway.net/article/.

Baharuddin Sayin, 2006. Pengenalan Pengurusan Wakaf di Malaysia. Shah Alam: Penerbit UiTM.

Che Zuina Ismail, 2015. Administration and Management of Waqf Land in Malaysia: Issues and Solution. Mediterranean Journal of Social Science MCSER Publishing, Rome-Italy, Vol. 6 No 4 S2 July 2015. ISSN 2039-2117, (2015): 613-620, diakses pada 27 November 2019. www.mcser.org/journal/index.php.

Harun bin Junid, 2012. Pengurusan Wakaf: Pengalaman Negara Brunei Darussalam. dibentangkan di Seminar Wakaf Serantau 2012. Sunway Putra Hotel, Kuala Lumpur, 3-6 September 2012. 
Hassan Langgulung, 1987. Asas-asas Pendidikan Islam. Jakarta: Pustaka al-Husna.

Hydzulkifli Hashim Omar dan Asmak Ab Rahman, (2015). Pembiayaan Pembangunan Harta Wakaf Menggunakan Sukuk. Kuala Lumpur: Penerbit Universiti Malaya.

Kamarudin Ngah, 1992. Isu Pembangunan Tanah Wakaf. Kuala Lumpur: Dewan Bahasa dan Pustaka.

Latar Belakang WAZAN. diakses pada 21 Ogos 2018. http://www.wazan. upm.edu.my/mengenai_kami/sejarah_dan_pengurusan_wazan/latar_ belakang_wazan-31538

Lihat Undang-Undang Republik Indonesia Nomor 41 Tahun 2004. Diakses pada 18 Julai 2016. http://www.beritawakaf.com/2014/02/undangundang-nomor-41-tahun-2004.html.

Lihat Administration of Muslim Law Act," diakses pada 18 Julai 2016. http://statutes.agc.gov.sg/.

Makdisi, George, 1981. The Rise of Colleges: Institution of Learning in Islam and The West. Edinburgh: Edinburgh University Press.

Maliah Sulaiman, 2009. Trust Me! A Case Study Of The International Islamic University Malaysia's Waqf Fund. International Association For Islamic Economics, Vol. 13 , No. 1, 2009.

Mas Nooraini binti Mohidin, 2015. Status WakafTunai di Brunei Darussalam: Sumbangannya ke Arah Pembangunan Ummah. Proceedings of International Conference on Cash Waqf 2015 (ICCW2015). Sepang: Malaysia.

Mohammad Tahir Sabit Mohammad, 2015. Theoretical And Trustees Perspectives On The Establishment Of An Islamic Social (Waqf) Bank. Humanomics, Vol. 31 Iss 1, (2015), 42. Diakses pada 3. April 2019, http://www.emeraldinsight.com.ezaccess.library.uitm.edu.my/doi/ pdfplus/10.1108/H-05-2013-0032. 
Mohd Afandi Mat Rani \& Siti Fatahiyah Mahamood, 2015. Isu-isu Perundangan Harta Wakaf di Malaysia. dlm. Rudy Heryana, pnyt. Proceeding $3^{\text {rd }}$ International Islamic Philantrophy: Pengembangan Komunitas ZISWAF Asia Tenggara. Jakarta: IMZ Publishing.

Mohd. Ali Muhamad Don, 2018. Aplikasi Model Teori Al-Wilayah: Cadangan Penyelesaian Konflik Perundangan Wakaf Di Malaysia. Jurnal Pengurusan dan Penyelidikan Fatwa. Vol. 13. No. 1, Julai 2018. Penerbit USIM.

Muna Sulaiman, 2013. Perkembangan Wakaf Pendidikan di Singapura. Diakses pada 21 Januari 2019. https://ejurnalfp.files.wordpress. com/2015/08/perkembangan-wakaf-pendidikan-di-singapura.pdf.

Murat Cizaka, 1998. Awqaf In History And Its Implications For Modern Economies. Islamic Economic Studies, Vol. 6, No. 1, November (1998).

Nurul Hilmiyah, 2013. Wakaf Produktif dalam Pembangunan Pendidikan: Kajian di Pondok Moden Darussalam Gontor Indonesia. (Prosiding PERKEM VIII, Jil. 3 2013), 1302-1314.

Rohayati Hussin \& Rusnadewi Abdul Rashid, 2015. Isu-isu Berkaitan Tanah Wakaf Halangan Kepada Pembangunan Institusi Wakaf Pendidikan Tinggi di Malaysia. Waqf Round Table Conference-IkaZ/ACIS, 12 Februari 2015.

Rohayu Abdul Majid \& Rosli Said, 2014. Permasalahan Pengurusan Hartanah Wakaf Di Malaysia. International Surveying Research Journal (ISrJ), Vol. 4, No. 1, Royal Institution of Survayors Malaysia ISSN 2232-1306, (2014).

Sayuti Ab Ghani, 2011. Amalan Pendaftaran Tanah Wakaf:Satu Kajian Kes Di Bawah Majlis Agama Islam Negeri Di Malaysia. Dibentangkan di International Conference 2011, Future Education in Global Challenges (ICETA 3), Hotel Garden Palace, Jawa Timur, Indonesia pada 19 April 2011. 
The Management of Waqf Universities in Selangor, Malaysia

Sharifah Zubaidah Syed Abdul Kader \& Nuarrual Hilal Md. Dahlan. Current Legal Issues Concerning Awqaf In Malaysia. Di akses pada 8 Ogos 2016, http://www.iefpedia.com/.

Siti Mashitoh Mahamood \& Asmak Ab Rahman, 2015. Financing Universities Through Waqf, Pious Endowment: Is It Possible?. Humanomics, Vol. 31 Iss 4, (2015): 432. diakses pada 6 April 2016, www.emaraldinsight.com/0828-8666.htm

Siti Mashitoh Mahamood \& Asmak Ab Rahman, 2014. Waqf financing For Higher Education: Contemporary Funding Aplications in Some Selected Countries. Dlm. Wan Kamal Mujani. pnyt. Pelestarian Institusi Wakaf Memperkasa Pendidikan Tinggi, Bangi: Fakulti Pengajian Islam UKM.

Siti Mashitoh Mahamood, 2006. Perundangan Wakaf Dan Isu-Isu Berbangkit. Dibentangkan di Konvensyen Wakaf Kebangsaan 2006. 12-14 Sept. 2006 di Hotel Legend Kuala Lumpur. 2006.

Siti Mashitoh Mahamood, 2010. Wanita dan Undang-undang Perspektif Undang-undang Harta dan Muamalat di Malaysia. al-Ihkam, Vol. V, No. 1 Juni (2010).

Siti Mashitoh Mahamood, 2007. Pembentukan Dana Wakaf Menurut Perspektif Syariah dan Undang-undang Serta Aplikasinya di Malaysia. Jurnal Syariah Vol. 15, No. 2, 2007, Kuala Lumpur: Penerbit Universiti Malaya.

Tunku Alina Alias \& Murat Cizakca, 2014. Should Malaysian States Have A Fresh Approach To Waqfs? A Proposal For A Model Waqf Enactment. ISRA International Journal of Islamic Finance, Vol. 6, Issue 2, 2014. Diakses pada 3 April 2018. http://web.a.ebscohost.com.ezaccess.library. uitm.edu.my/

Wan Mohammad Hafiz bin Wan Mat Resab \& Zulkifli bin Mohammad. (t.th.). Peranan Jawhar Dalam Pembangunan Wakaf Di Malaysia. Diakses pada 8 Ogos 2018. http://ukmsyariah.org/terbitan/wp-content/ uploads/2015/09/32-Wan-Mohammad-Hafiz-bin-Wan-Mat-Resabedited.pdf . 
Journal of Contemporary Islamic Studies

Saad, N. M., Sarif, S. M., Osman, A. Z., Hamid, Z., \& Saleem, M. Y, (2017). Managing Corporate Waqf in Malaysia: Perspectives of Selected SEDCs and SIRCs. Jurnal Syariah, 25(1), 91-116.

\section{STATUTORY LIST}

Admistration of Islamic Law Enactment (Negeri Selangor) 2003

Wakaf Enactmet (Negeri Selangor) 2015

Perlembagaan Persekutuan (2014), Petaling Jaya, International Law Book Sevices.

\section{LIST OF PARTICIPANTS:}

P02 is Administers of waqf scheme in university P03 is Officer of Perbadanan Wakaf Selangor P04 is Law advisor of Selangor IRC P06 is CEO of Koperasi Syariah, ANGKASA P07 is CEO of Dewan Perdagangan Islam Malaysia 